\title{
THE MESOLITHIC RESEARCH OF A DECADE: EARLY HOLOCENE SETTLEMENTS IN TRANSDANUBIA
}

\author{
Tibor Marton ${ }^{1}$ - Róbert Kertész ${ }^{2}$ - William J. EichmanN ${ }^{3}$ \\ Hungarian Archaeology Vol. 10 (2021), Issue 2, pp. 1-14. https://doi.org/10.36338/ha.2021.2.5
}

\section{In memoriam Balázs Dákó}

Despite the promising research trends of the last decades, it is striking that traces of Mesolithic settlements have only rarely come to light in the Carpathian Basin so far. The area of Transdanubia is not an exception. With the cooperation of three institutes, a research program was launched in 2003 with the aim of discovering new find places of the period, as well as re-evaluating finds that had been taken to museums earlier and classified as Mesolithic. The field surveys revealed Early Holocene sites in the South-East Transdanubian region in the valley of the Kapos and Koppány Rivers, mainly in the outskirts of Kaposhomok and Regöly. The sites mainly came to light on the island-like reliefs elevating only a few meters from the present-day floodplain. The dating of the surface finds, especially chipped stone artefacts, was primarily based on the geometric microliths, which contain asymmetric triangles, segments, and trapezes. We could even reveal Mesolithic finds within stratigraphic position at the site of Regöly 2, where the remains of a domestic structure also came to light.

Keywords: Mesolithic, Early Holocene, South Transdanubia, Regöly, geometric microlith

\section{INTRODUCTION}

For a long time, only stray finds and finds of uncertain provenance were known in the Carpathian Basin from the period between the Palaeolithic and the Neolithic (i.e. the Mesolithic). Excavations only took place at the sites of Sződliget, Szekszárd-Palánk, and Eger-Köporos-tető (VÉRTES 1965). However, by the 1980s it became clear that the site of Eger and the assemblages classified to the same culture dated from the Palaeolithic, which led to the assumption that due to the northward migration of the hunting groups at the end of the Ice Age, the Carpathian Basin became almost unpopulated (GÁBORI 1984). Although during the last decades, the number of Mesolithic settlements has significantly increased, these are still only sporadic observations. The finds revealed in the course of the regular surveys performed in the Jászság region from the 1990s onwards (Kertész 2002, 2003, 2005; GutAY \& KerÉKGYÁRTó 2019) made it possible to fit the Early Holocene inhabitation of this region within the European Mesolithic (KERTÉsz 2002). Recently, the excavation of the site of Páli-Dombok has enriched the number of Mesolithic find places in the region of Transdanubia (Mester et al. 2014). Besides the new discoveries, the re-evaluation of the already known find assemblages also transformed the picture drawn by earlier research results. The technological and typological comparison of all the finds excavated at the two Mesolithic sites in the Danube Bend, on the outskirts of Sződliget (GÁBORI 1956; 1968) revealed that they were not contemporaneous but represented the early and late phases of the Mesolithic (Kraus 2011). The re-evaluation of the finds from Szekszárd-Palánk highlighted that inhabitants of the site must have maintained relations with distant areas, since their raw materials included even flints originating from beyond the Carpathians (KerTész \& Demeter 2020).

As an initiative of this article's authors, a cooperation program was launched with the participation of the Damjanich János Museum, the Archaeological Institute of the Hungarian Academy of Sciences, and the University of Wisconsin-Madison, Department of Anthropology in 2003, the aim of which was to re-eval-

\footnotetext{
Eötvös Loránd Research Network Research Centre for the Humanities, Institute of Archaeology E-mail: marton.tibor@btk.mta.hu

Damjanich János Museum. E-mail: kertesz@djm.hu

Environmental Resources Management. E-mail:wjeichmann@erm.com
} 
uate the finds that had been taken to museums earlier and considered Mesolithic, as well as to discover new find places (EICHMANN et al. 2010).

The finds originating from surface collections can often only be dated on a typological basis. Among the geometric microlith types considered typical of the Mesolithic (KozŁOwSKI 2003, XVIII), only the ones with isosceles and asymmetric triangle shape are exclusively characteristic of the Mesolithic finds in the Carpathian Basin, since trapezes and segments were also present in the Neolithic and Copper Age stone industry (Biró 2002; Mateiciucová 2008; Tolnai-Dobosi 1968; Marton 2002).

\section{INVESTIGATIONS IN MUSEUM COLLECTIONS: THE RE-EVALUATION OF OLD FINDS}

A critical analysis of the finds stored in museums and known in the archaeological literature is a significant aspect of the research of Mesolithic sites. We analysed all the finds dated to the Mesolithic on the basis of various notions but without absolute chronological data, considering both technological-typological circumstances and provenance. As a result, most of these sites were excluded from the possible Mesolithic find places, or proved to be unsuitable for further investigations (EICHMANN et al. 2010, 216-217, Marton 2003; Kertész \& DemeTER 2020). Such are the finds from the outskirts of Györ (Koroncó, Románd, Bakonytamási), the sites of the Vázsony Basin (Mencshely, Vöröstó), and Pamuk. Besides the site of Szekszárd-Palánk, only the bone harpoons found in Sárrét and the chipped

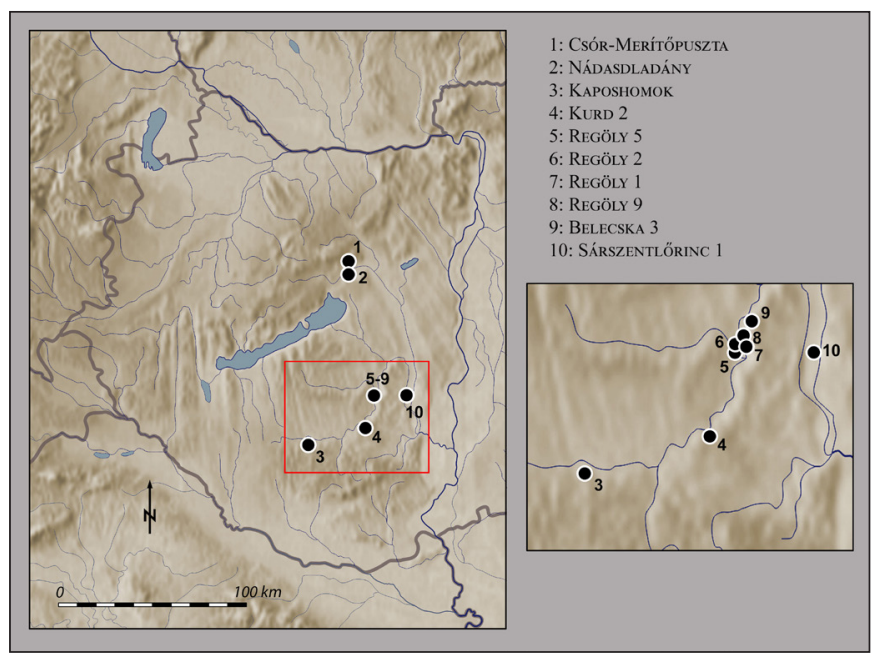

Fig. 1. The research area with the sites discussed in the article (graphics: T. Marton and Zs. Réti) stone artefacts from Kaposhomok could possibly be considered Mesolithic in the beginning of the research program (Fig. 1).

\section{The harpoons from Sárrét}

There are two bone harpoons in the inventory of the Szent István Király Museum in Székesfehérvár. The artefacts were registered under the site names Csór-Merítőpuszta and Nádasdladány. While the piece from Nádasdladány is available today, the other one from Csór was lost under unknown circumstances, only two

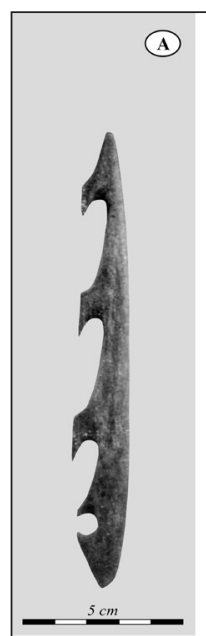

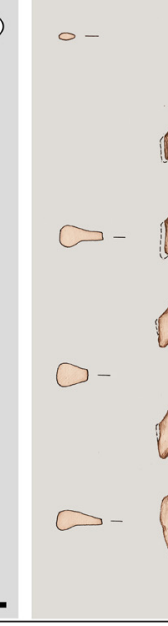

Fig. 2. A: the bone harpoon from Csór-Meritöpuszta (photo by MAROSI 1935); B: the bone harpoon from Nádasdladány (graphics: T. Marton-Zs. Réti) photos remained of it.

The typological connection between the two single-rowed harpoons is undoubtable. While the length of the one from Csór is $15.7 \mathrm{~cm}$ and it has three barbs (Fig. 2.A), and the other one from Nádasdladány is $21.1 \mathrm{~cm}$ long and has five barbs (Fig. 2.B), their shaping is completely identical. Their outer edge is square, and they are rounded inside. A rounded incision is visible on the base of both harpoons, sideways on the one from Csór, and on the longitudinal axis in the case of the other one from Nádasdladány. This detail suggests that harpoons were only loosely attached to the shaft, and a string was tied to their basis (VERHART 2000, 114).

Arnold Marosi published the harpoon from Csór (Marosi 1935; 1936a; 1936b). He argued for its Mes- 
Tibor Marton et al. $\bullet$ The Mesolithic Research of a Decade: Early Holocene Settlements in Transdanubia

olithic dating primarily by the formal analogies of the Maglemosian culture. Although his reasoning was accepted later (NEMESKÉRI 1948; DoBOSI 1975, 68), some researchers emphasized the uncertainty of dating based exclusively on typological arguments (VÉrTES 1965, 216; KERTÉSZ, 1993, 89). Together with the harpoon from Csór, János MAKKAY drew attention to the one from Nádasdladány $(1970,14)$, the exact provenance of which is unknown. He dated these harpoons to the Late Upper Palaeolithic on typological grounds, however, researchers later assumed Mesolithic dating based on the geochronological circumstances of this region (BÁNFFY et al. 2007, 226; EICHMANN et al. 2010, 217).

The two harpoons have only one precise anal-

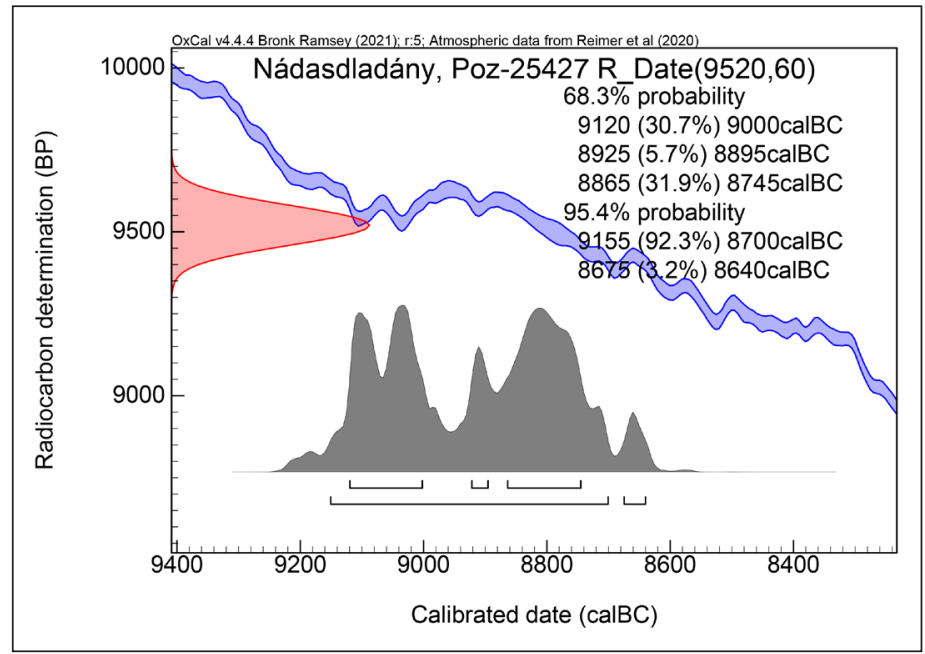

Fig. 3. The radiocarbon dating of the bone harpoon from Nádasdladány ogy among the Stone Age sites in Hungary. A piece similar in shape came to light at the site of MezölakSzélmezö from a similarly peaty area, however, the form of the barbs is different, and the base has no incision (HoRvÁth \& Ilon 2017, 162, Fig 7: 6). The radiocarbon sample taken from it (DeA-4878) dates this piece to the period between 11,777-11,506 BC, thus it is older than the beginning of the Mesolithic. The radiocarbon dating of the harpoon from Nádasdladány resulted in a period between 9160-8700 BC (Fig. 3), meaning that it comes from the beginning of the Early Mesolithic (KACZANOWSKA \& KozŁowsKi 2014). Unfortunately, the bone artefact from Szekszárd-Palánk that László Vértes defined as a harpoon (VÉRTES 1962, 179, Taf. 5: 24) is too fragmented to be comparable with the pieces from Sárrét.

\section{A Mesolithic site in Kaposhomok}

Rezső Pusztai carried out a surface survey in Kaposhomok in the beginning of the 1950s (PuszTAI 1957). The aim of our research was to identify the site, and to re-evaluate the finds stored in the collection of the Rippl-Rónai Museum (Marton 2003; Eichmann et al. 2010). Besides chips and regular blades, the find assemblage (Fig. 4. 2-7, 9-19) included small end-scrapers, drills, rounded retouched points, points with shaft, truncated blades, and among the geometric microliths asymmetric triangles, isosceles triangles, and trapezes. Their raw material is mainly radiolarite from the Mecsek and in a smaller part from the Bakony Mountains. These types of lithic artefacts leave no doubt that they date from the Mesolithic.

A local resident, Antal Trombitás had collected the finds published by Pusztai. He helped us in 2003 to identify the site located at the right bank of the Kapos River, on a dune elevating from the floodplain 121$125 \mathrm{~m}$ above sea level. We even found a trapeze and a backed blade among the remains of the chipped stone artefacts in the original collection of Antal Trombitás (Fig. 4. 1, 8).

\section{Field surveys in the Kapos and the Koppany Valleys}

These results proved that it would be reasonable to search for Early Holocene settlements in the Kapos Valley. We focused our attention to the surroundings of Regöly located at the Kapos-Koppány interfluve, where a local, Viktor Cziráki had collected surface finds since the 1980s. Based on the geometric microliths among his finds, we decided on further research at several sites (EICHMANN et al. 2010).

The most significant among them is Regöly 2 (Fig. 5), which yielded nearly 1200 chipped stone artefacts (Fig. 6. 1-10). Besides the great number of flakes, the assemblage also included regular blade cores and relatively large blades, as well as small, sometimes truncated blades with sickle gloss. Various types of end-scrapers and drills were also found. The common occurrence of some straight or backed blades and trapezes proved the Mesolithic dating of the site. Stone grinders, a partly pierced pebble with red paint and a dentalium bead also came to light. Although variants of radiolarite from the Mecsek dominate among the 


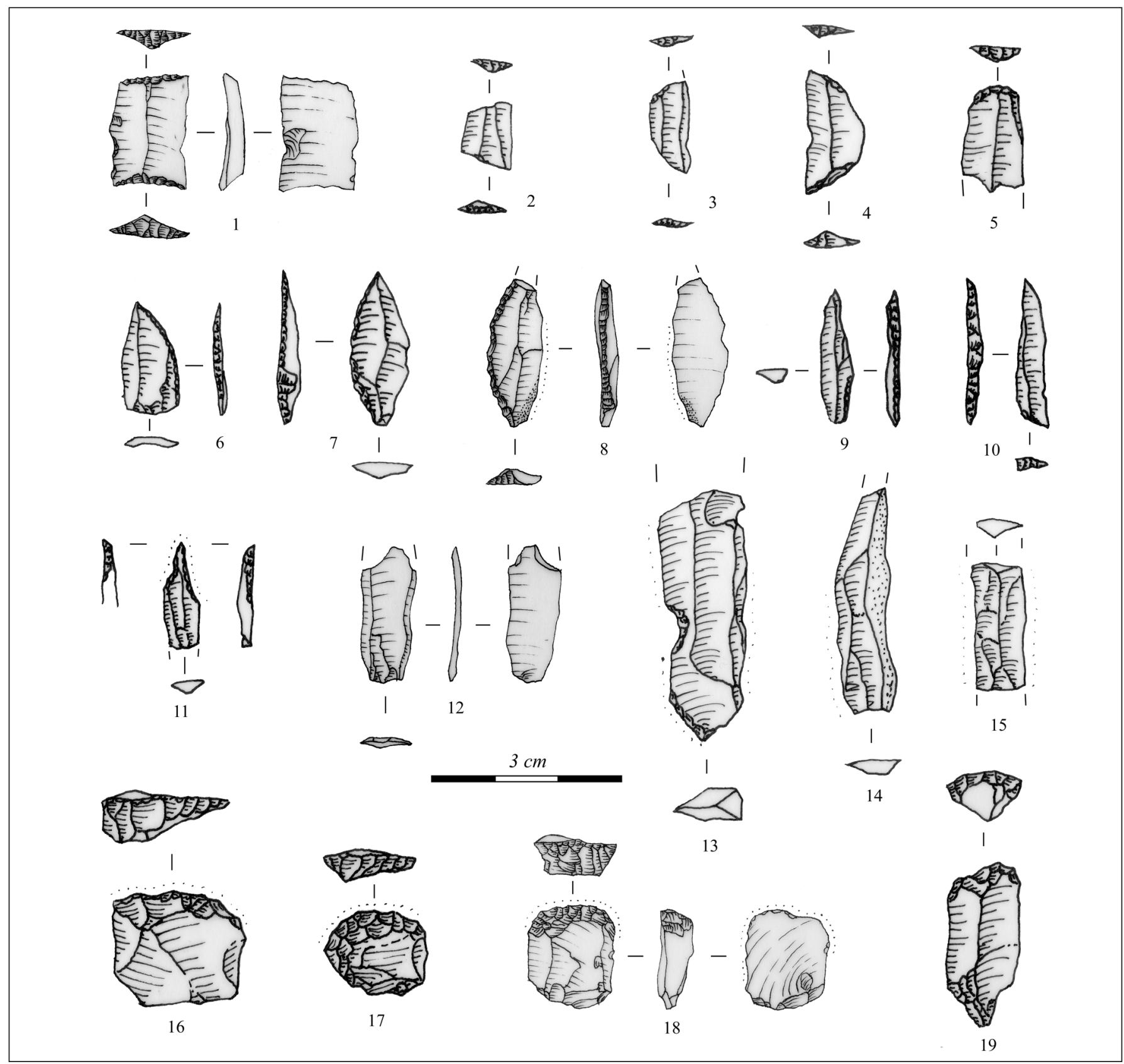

Fig. 4. Chipped stone artefacts from Kaposhomok: 1-4: trapezes; 5: truncated blade; 6: retouched point; 7: tanged point with shaft; 8: backed blade; 9: isosceles triangle; 10: asymmetric triangle; 11: drill; 12-15: blades; 16-19: end-scrapers (graphics: T. Marton).

raw materials of the chipped stone artefacts, Bakony types also occur in great numbers, as well as two obsidian fragments, and some dark grey radiolarites.

The site is located east of Regöly, at the right bank of the Koppány River, some 150 metres from the current, regulated bank, 103-105 metres above sea level. The hill elevating firmly from the floodplain of the Koppány is cut through by a one-time riverbed, therefore we divided the site as Regöly $2 \mathrm{a}$ and $2 \mathrm{~b}$. We performed a systematic surface collection between 2004 and 2009, during which we

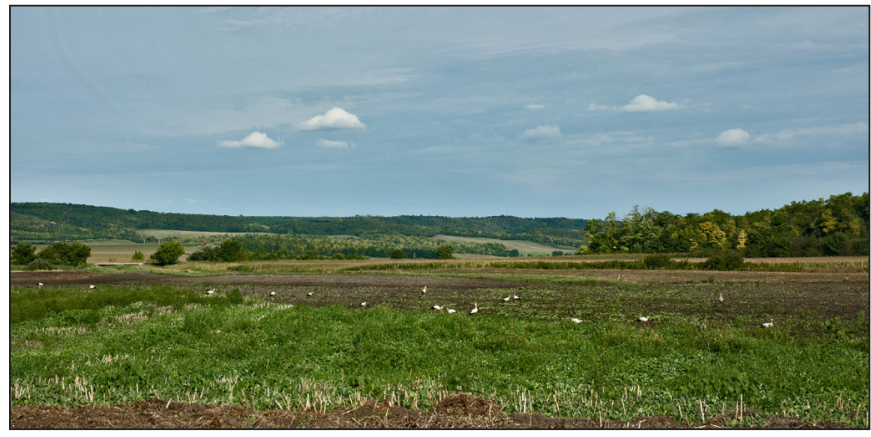

Fig. 5. The site of Regöly 2 at the floodplain of the Koppány (photo: W. J. Eichmann) 


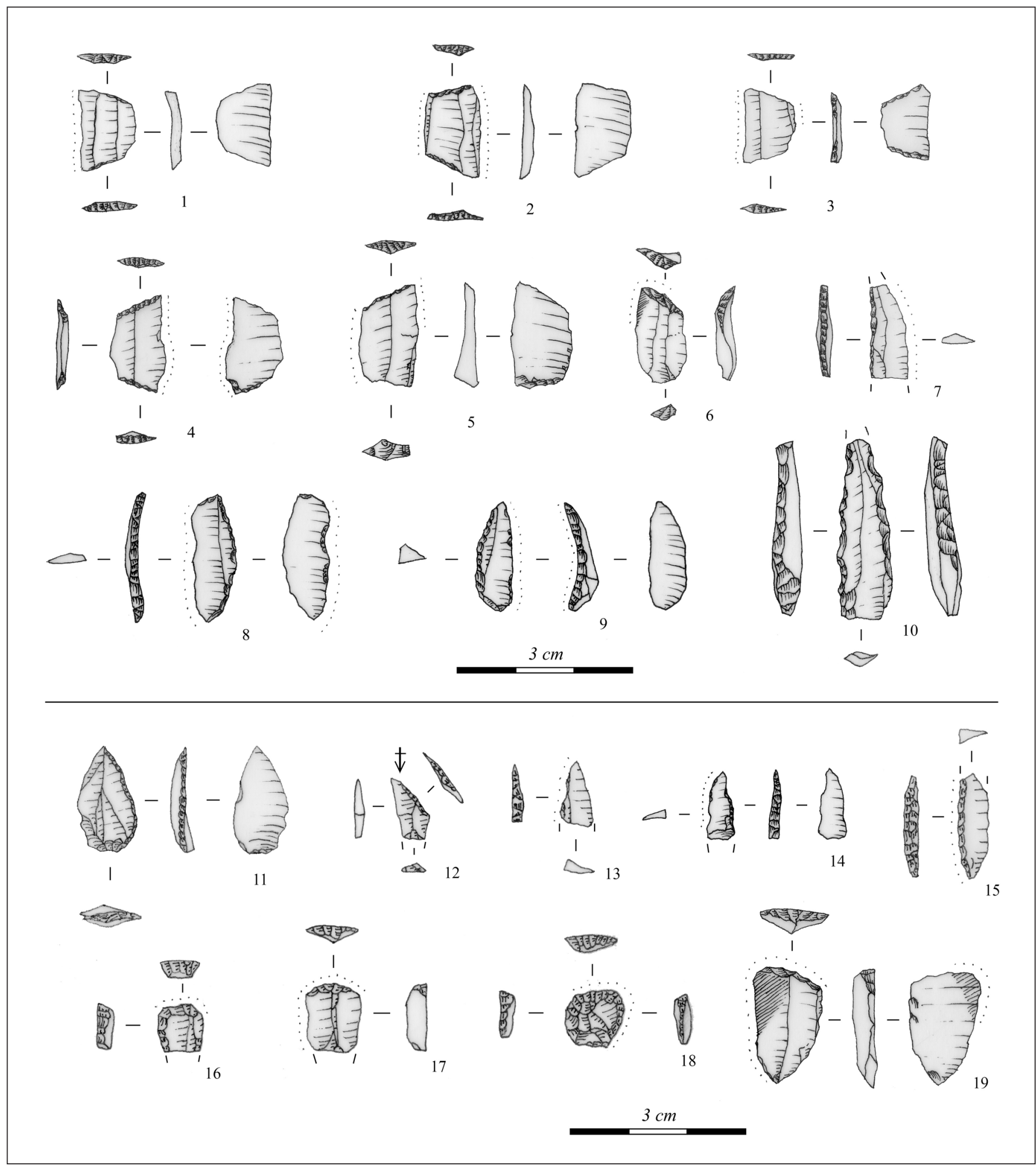

Fig. 6. Chipped stone artefacts from the site of Regöly 2 (1-10: the collection of Viktor Cziráki; 11-18: the find material from the systematic field survey): 1-5: trapezes; 6, 12, 19: truncated blade; 7, 14-15: backed microblade; 8-9: backed blade; 10: drill; 11: retouched point; 13: backed point; 16-18: end-scrapers (graphics: T. Marton)

recorded the precise location of each finds within a $5 \times 5 \mathrm{~m}$ grid (Fig. 7). We observed the densest concentration of finds in the central part of Site 2a, in a $100 \times 70 \mathrm{~m}$ area. A characteristic Mesolithic find assemblage came to light as a result of the systematic survey (Fig. 6. 11-19).

Regöly 1 is located northeast of Regöly 2, at the left bank of the Koppány River (EICHMAnN et al. 2010, 227). The hill elevating 3-4 m from the floodplain is situated at the bank of one of the Koppány's one-time 
Tibor Marton et al. $\bullet$ The Mesolithic Research of a Decade: Early Holocene Settlements in Transdanubia

meanders, $103 \mathrm{~m}$ above sea level. During our field survey in 2003, even shards related to the Central European Linear Pottery culture came to light. However, in 2010 we identified a concentration of finds in an area $70 \mathrm{~m}$ in diameter, which raises the possibility of the site dating from the Mesolithic. The majority of the 385 finds is chipped stone artefacts, including asymmetric triangles, truncated blades, and backed microblades, and their raw material is almost exclusively radiolarite from the Mecsek (Fig 8. 1-8).

The site of Regöly 5 is located ca. $1 \mathrm{~km}$ west of the Kapos-Koppány interfluve, at the bank of a one-time meander, $102 \mathrm{~m}$ above sea level. The finds collected during systematic field surveys, including a significant amount of pottery shards and animal bones associated with the Bronze Age Kisapostag culture in addition to the chipped stone artefacts, were scattered in an area of nearly $100 \times 100 \mathrm{~m}$. Based on the finds in Viktor Cziráki's collection, the symmetric and asymmetric trapezes, blades truncated at both

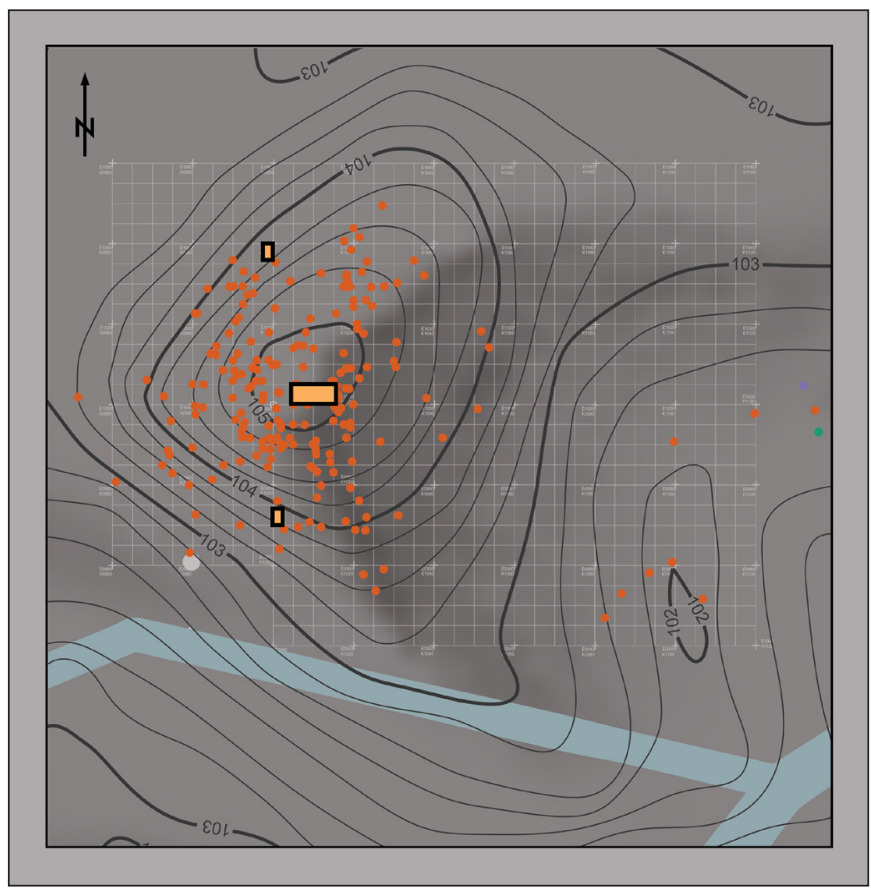

Fig. 7. The surface distribution of the finds, and excavation trenches at Regöly 2 (graphics: W. J. Eichmann) ends, segments, and drills made from radiolarite from the Mecsek and the Bakony, one may assume that these finds date from the Mesolithic (Fig. 9. 1-14).

We also carried out surface collection at some further sites northeast of Regöly, by the bend of the Kapos, among which the site Belecska 3 provided important data related to our topic (EIcHMAnN 2004, 187). The finds were scattered in a circle with a ca. $50 \mathrm{~m}$ radius at the right bank of the one-time river meander, $102 \mathrm{~m}$ above sea level, which elevates nearly 2-3 m above the level of the one-time riverbed. Among others, the 72 chipped stone artefacts predominantly made from radiolarite from the Mecsek, included a triangle isosceles and a backed microblade (Fig. 9. 15-16), which raises the possibility that the site dates from the Mesolithic.

A find assemblage named Kurd 2 (EICHMANN 2004, 187) near Kurd, at the right bank of the regulated Kapos bed, ca. $1.5 \mathrm{~km}$ north of the settlement, includes chipped artefacts with a rounded backed blade truncated at the base as well as other truncated blades, which do not exclude their Mesolithic dating. However, as the number of these finds is too small, they are no irrefutable evidence.

Knowing the geological conditions of the find places that Viktor Cziráki discovered, we performed systematic surface surveys by the above mentioned individual find recording method on locations with similar features. As a result, we discovered two further sites, where among others, traces of Mesolithic inhabitation could be observed. One of them is Regöly 9, located 100-150 m north of the interfluve of the Kapos and Koppány Rivers, on a sand dune running in parallel with the river, and elevating 3-4 m from its environment. The chipped stone artefacts that came to light at the north-western part of the site include microblades, segments, truncated blades, a drill, and short end-scrapers typical of the Mesolithic (Fig. 8. 9-16). The dominance of radiolarites from the Mecsek is evident even among the raw materials.

Another site came to light in the vicinity of Sárszentlörinc during the preliminary field surveys, which can be connected to the one-time watercourse system of the Sárvíz and the Sió. The site elevates 1-2 m above the floodplain. During the systematic field survey in 2009, we observed that the finds were concentrated in a 200 $\times 50-70 \mathrm{~m}$ area on the southern side of the hill. Pottery shards certainly dating from the Early Neolithic Starčevo culture also came to light from the vicinity of the chipped stone artefacts. The grinding stones and stone grinder fragments also prove the Neolithic inhabitation of the site. A trapeze and a backed point can also be found among the chipped stone artefacts, which even raises the possibility of a Mesolithic inhabitation (Fig. 8. 17-22). This find place may be of key importance regarding the comparison of Mesolithic and Early Neolithic settlement structures, and the spread of the Neolithic. 
Tibor Marton et al. $\bullet$ The Mesolithic Research of a Decade: Early Holocene Settlements in Transdanubia

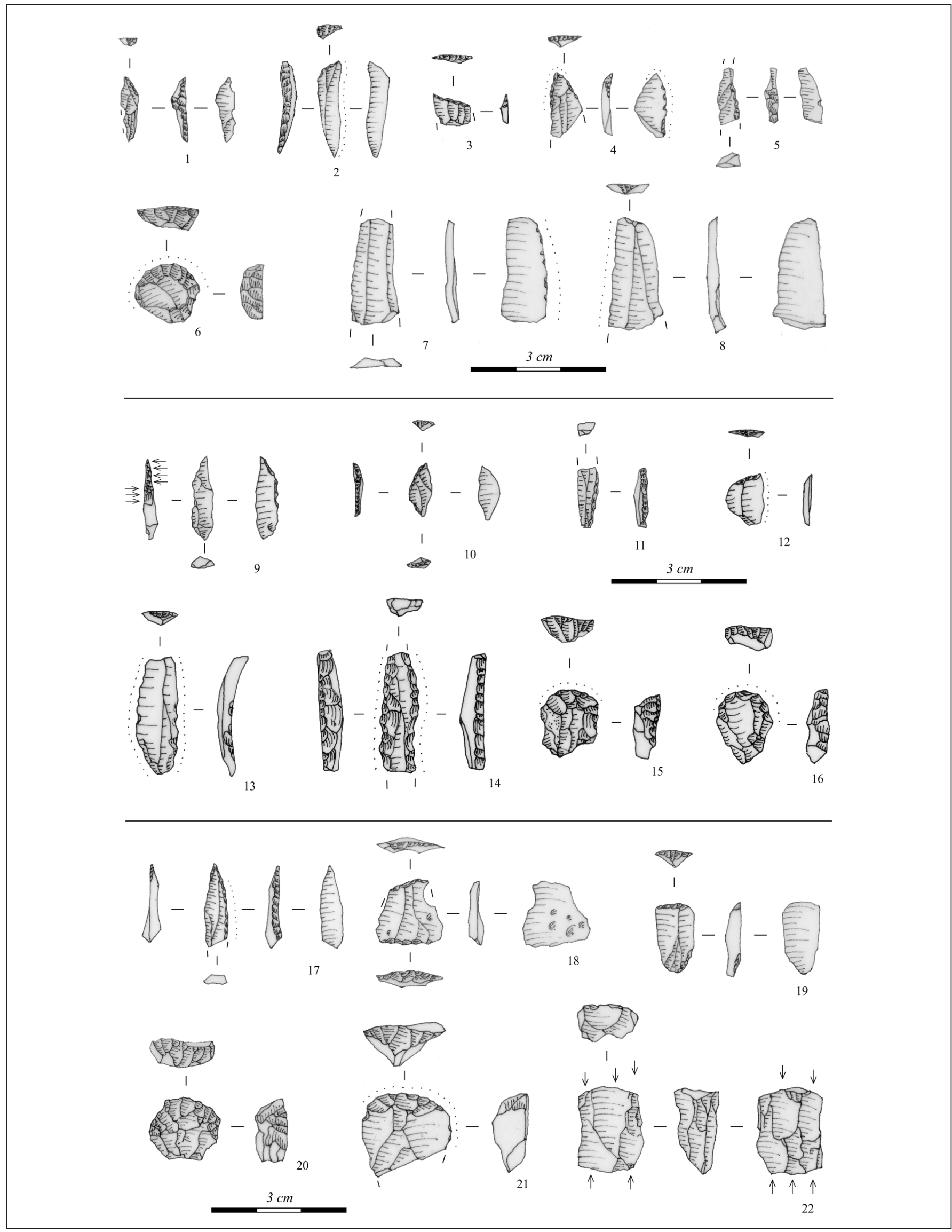

Fig. 8. Chipped stone artefacts from the sites Regöly 1 (1-8), Regöly 9 (9-16), and Sárszentlörinc 1 (17-22): 1-2: asymmetric triangles; 3-4, 12-13: truncated blades; 5, 9, 11: backed microblades; 6, 15-16, 19-21: end-scrapers; 7-8: blades; 14: drill; 17: backed point; 18: trapeze; 22: core (graphics: T. Marton) 
Tibor Marton et al. $\bullet$ The Mesolithic Research of a Decade: Early Holocene Settlements in Transdanubia

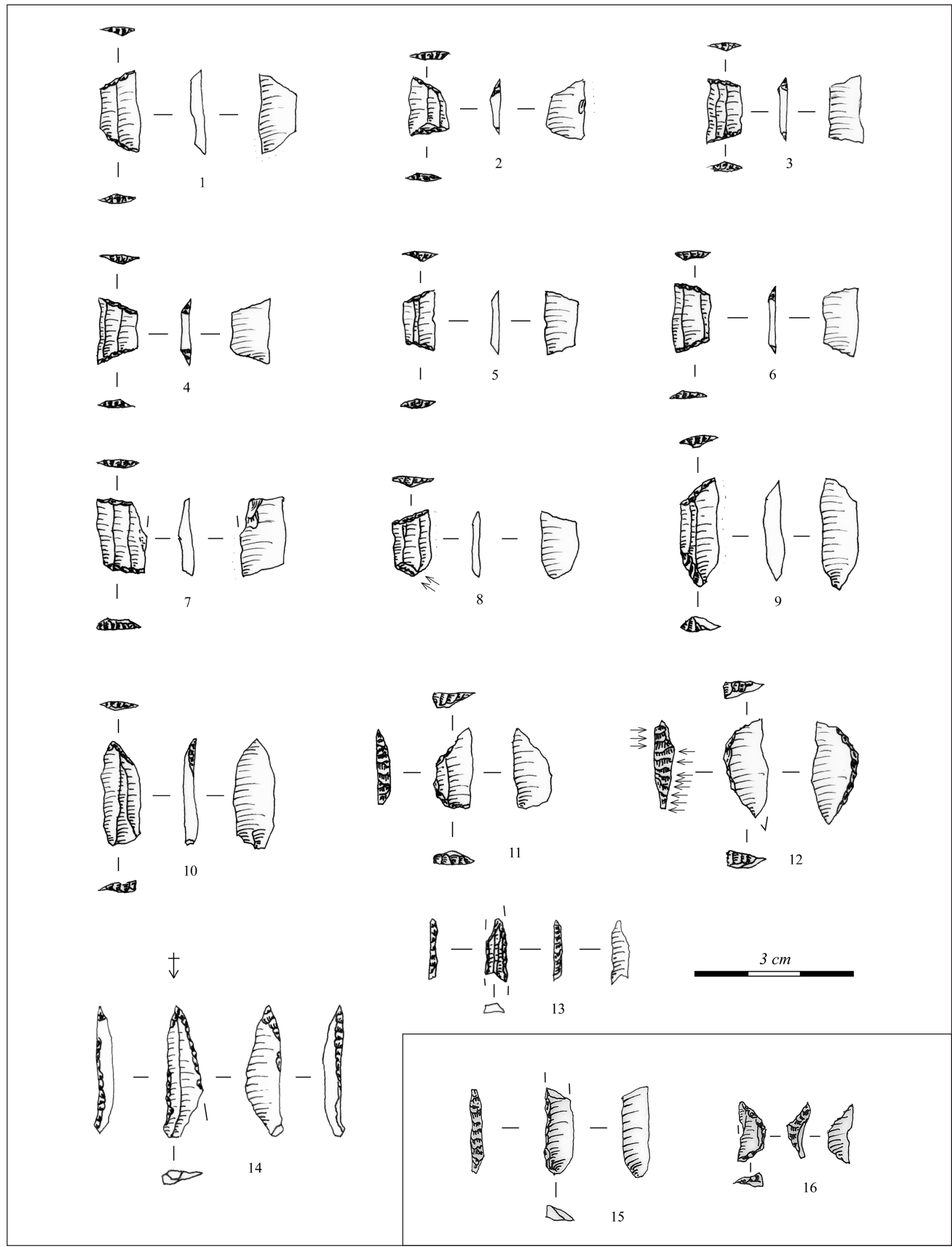

Fig. 9. Chipped stone artefacts from the sites of Regöly 5 (1-14) and Belecska 3 (15-16): 1-6, 8-9: trapezes; 7, 10: blade truncated at both ends; 11-12: segments; 13-14: drills; 15: backed microblade; 16: triangle isosceles (graphics: T. Marton) 
Tibor Marton et al. $\bullet$ The Mesolithic Research of a Decade: Early Holocene Settlements in Transdanubia

\section{EXCAVATIONS AT REGÖLY 2}

Based on the preliminary observations, we assumed that the Mesolithic site of Regöly 2 was undisturbed. We began the excavations here in 2004, and continued with minor interruptions until 2009. First, we opened three $1 \times 2 \mathrm{~m}$ sondages for a more precise localization of the above mentioned find concentration, among which one yielded an asymmetric triangle (Fig. 12. 1). We recorded the stratigraphic data in one square metre grids, by $5 \mathrm{~cm}$ thick layers. Due to the small size of finds in the first year, we dry sieved all the excavated earth by a sieve with $5 \mathrm{~mm}$ grids, while we applied wet sieving in the following years.

We opened a trench of $6 \times 6 \mathrm{~m}$ in the central part of the hill (Block 1), and two sections of $2 \times 4 \mathrm{~m}$ in its western part (Blocks 2 and 3) (Fig. 7). A shallow pit with flat bottom was discovered in a depth of 35-40 $\mathrm{cm}$ at the western end of Block 1, in the side of which we uncovered three upright and shallow postholes (Fig. 10). In continuation to that, we opened another $6 \times 6 \mathrm{~m}$ section in 2008-2009, where the other part of the pit came to light, which turned out to be a round feature ca. $4 \mathrm{~m}$ in diameter, with an average depth of $25 \mathrm{~cm}$ (Fig. 11). We found the postholes cut into its edge, and in the

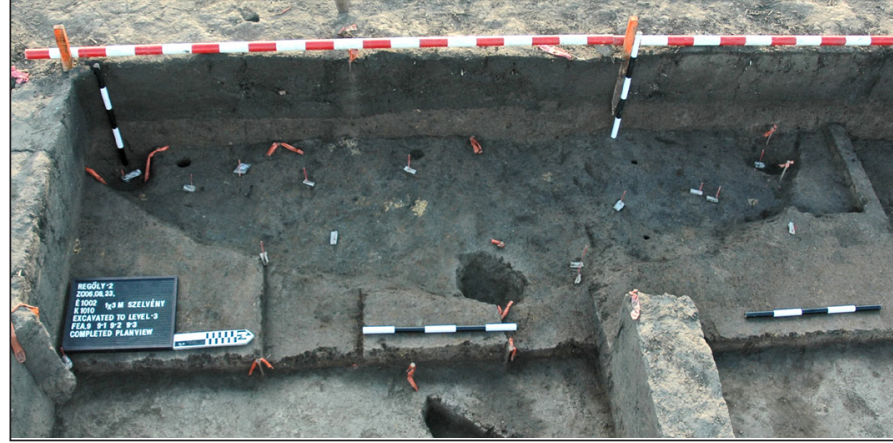

Fig. 10. Remains of the Mesolithic building structure during the excavation at Regöly 2 (photo: W. J. Eichmann) case of the deeper ones, even the inclination angle could be measured. This feature can most certainly be identified as a domestic building, which has a close parallel in Jásztelek I: the foundation of a hut with a round ground plan ca. $5 \mathrm{~m}$ in diameter and with a posthole structure (KerTÉsz 1996, 19-22, Figs 12-13; KerTÉsz 2002, 288, Figs 5-6).

Chipped stone artefacts and animal bone fragments were scattered in its interior and surroundings in a relatively equal proportion. Besides the conical, orthogonal, and irregular blade cores, the characteristics

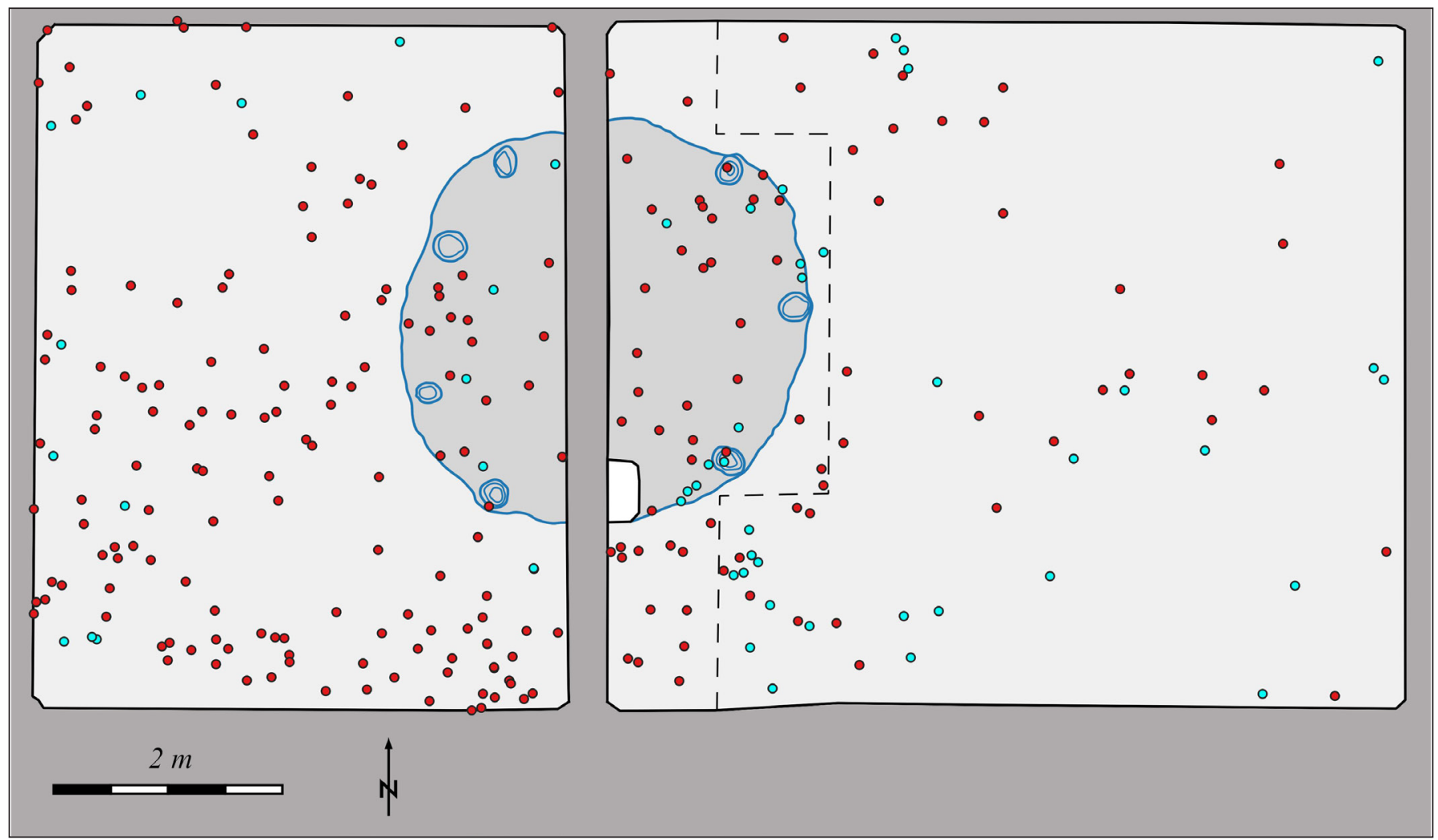

Fig. 11. The ground-plan of the Mesolithic building at Regöly 2 (red dot: chipped stone artefacts, blue dot: animal bones) (graphics: W. J. Eichmann - B. Vágvölgyi) 
Tibor Marton et al. • The Mesolithic Research of a Decade: Early Holocene Settlements in Transdanubia

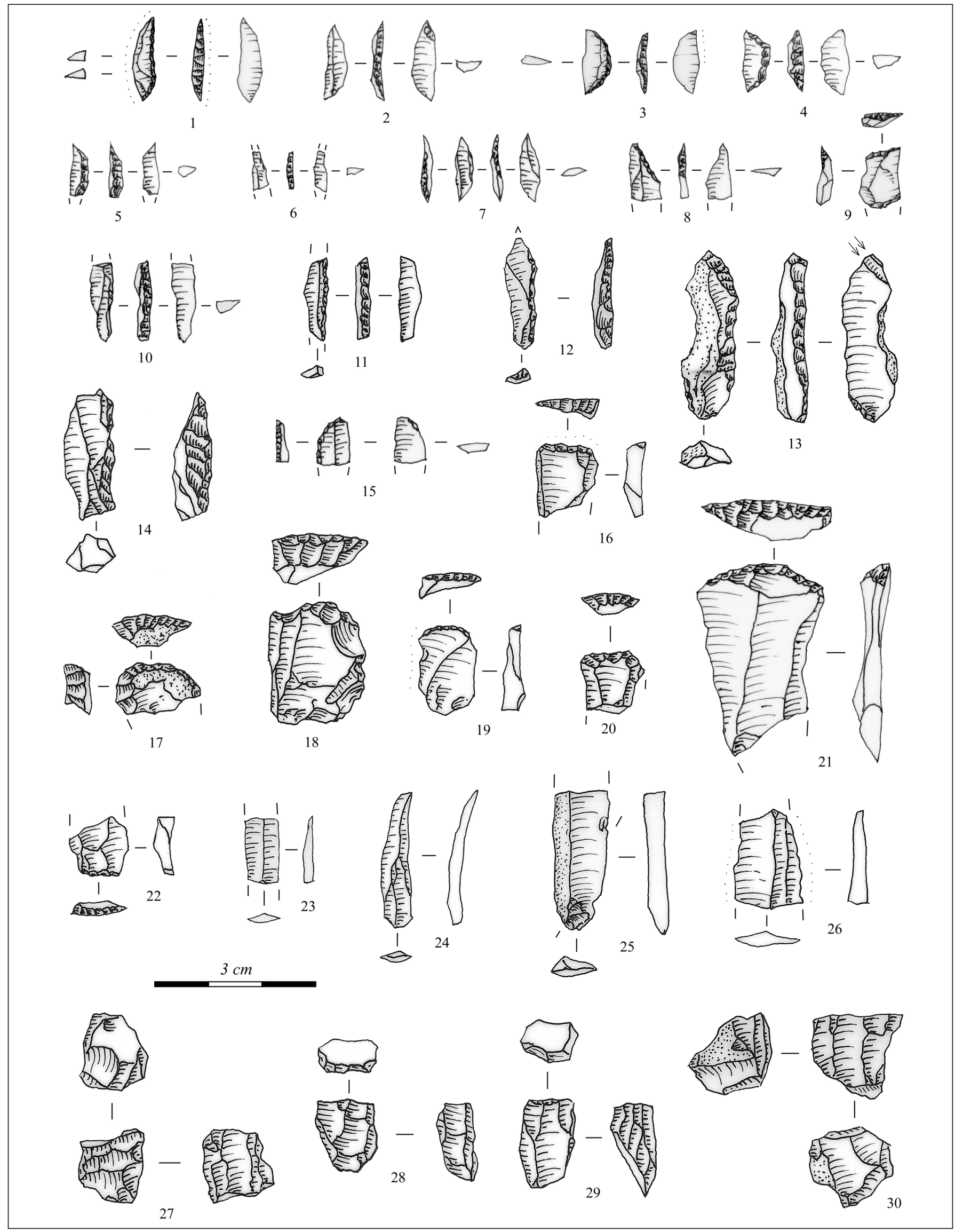

Fig. 12. Chipped stone artefacts from Regöly 2: 1. asymmetric triangle; 2-5: segments; 6-7, 10-12: backed microblades; 8-9, 16: truncated blades; 13-15: retouched blades; 17-22: end-scrapers; 23-26: blades; 27-30:cores 
of the anvil technique can also be observed on the find assemblage (Fig. 12). Blades are usually small, and some of them raise the possibility that they were produced by pressure technique. Retouched artefacts included backed microblades, truncated blades, end-scrapers on flake and blade, and retouched blades. Geometric microliths are represented by asymmetric triangles and segments. The raw material of the finds is mainly radiolarite from the Mecsek, and radiolarite from the Bakony in a smaller part.

Although the surface of the extremely fragmented bones is highly eroded, we uncovered an almost intact animal rib at Block 2, on the sandy surface under the topsoil $80 \mathrm{~cm}$ thick in average (EICHMANN et al. 2010, 226). This latter observation raises the possibility that there may be settlement traces buried by river sediment in the surroundings of the site.

\section{SUMMARY}

In absence of absolute chronological data, it is only possible to classify the above discussed find places as Mesolithic on the basis of the typological analysis of stone artefacts, which revealed their common features. The topographic situation of the sites is also very similar, they are all located on smaller elevations in floodplain areas, at the bank of one-time meanders, at an altitude of 102-105 m near Regöly, and $125 \mathrm{~m}$ above sea level in Kaposhomok. Radiolarite from the Mecsek obviously dominate among the raw material of the stone artefacts, however, a part of the raw material may have been collected from gravel sediments. Microblades and cores used for their manufacture dominate in stone industries, and while traces of the anvil technique are visible, the microburin production technique has no direct evidence. Short end-scrapers are characteristic of these sites, and almost all of them yielded drills. Asymmetric triangles and segments dominate among the geometric microliths, however, they only form a minor segment of the entire find material. The occurrence of trapezes at the site of Regöly 2 is quite problematic: while they were found during earlier collections, none came to light during the excavation. Since differences can be observed between the finds of the collections and the excavations both in respect of technology and raw material, we may presume that agricultural activities have already destroyed a Late Mesolithic layer, to which the trapezes belonged (Kertész 1996, 24; KozŁowski 2001; Krauss 2016, 196).

Any kind of cultural classification would be methodically problematic due to the mixed nature of the finds collected during the field surveys and the small number of excavations. However, the typology of points, the presence of geometric microliths, and the extremely small backed blades suggest a possible connection with the Western European technocomplexes, especially with the Sauveterrien-type finds (KozŁOwSKI 2001). So far, research has primarily focused on the identification of find places, and we do not have any data concerning the life of the one-time communities yet. The detailed analysis of finds, and the conclusions drawn from environmental conditions will help further studies.

\section{ACKNOWLEDGEMENT}

Our research has been supported by the Fullbright Program and OTKA (K 61935). We hereby thank Viktor Cziráki and Robert Eichmann for their invaluable support. We would like to express our gratitude to the many high school and university students, colleagues, and residents who participated in the projects.

\section{BIBLIOGRAPHY}

Bánffy, E., Juhász, I. \& Sümegi, P. (2007). A prelude to the Neolithic in the Balaton region: new results to an old problem. In M. Spataro, \& P. Biagi (eds), A Short Walk through the Balkans: The First Farmers of the Carpathian Basin and Adjacent Regions. Proceedings of the Conference held at the Institute of Archaeology UCL on June 20th-22nd, 2005. Società per la Preistoria e Protostoria della Regione Friuli Venezia Giulia, Quaderno 12, Trieste (pp. 223-237). Trieste: Società per la preistoria e protostoria della regione Friuli-Venezia Giulia. 
Tibor Marton et al. $\bullet$ The Mesolithic Research of a Decade: Early Holocene Settlements in Transdanubia

T. Biró, K. (2002). Advances in the study of early Neolithic lithic materials in Hungary. Antaeus 25 (2002), 119-168.

Dobosi, V. (1975). Magyarország ős-és középső kőkori lelöhely katasztere [A registry of Paleolithic and Mesolithic sites in Hungary]. Archaeológiai Értesitö 102 (1975), 64-76.

Eichmann, W. J. (2004). Mesolithic hunter-gatherers in the Carpathian Basin and the spread of agriculture in Europe. In I. Huszár (ed.), Fulbright Student Conference Papers. Academic Years 2002/2003 and 2003/2004 (pp. 161-202). Budapest: Hungarian-American Commission for Educational Exchange.

Eichmann, W. J., Kertész, R. \& Marton, T. (2010). Mesolithic in the LBK heartland of Transdanubia, Western Hungary. In D. Gronenborn \& J. Petrasch (eds), The Spread of the Neolithic to Central Europe. Part 1 (pp. 211-233). Mainz: Verlag des Römisch-Germanischen Zentralmuseums.

Gábori, M. (1956). Mezolitikus leletek Sződligetről (Mesolithische Funde von Sződliget). Archaeologiai Értesitö 83 (1956), 177-182.

Gábori, M. (1968). Mesolithischer Zeltgrundriss in Sződliget. Acta Archaeologica Academiae Scientiarum Hungaricae 20 (1968), 33-36.

Gábori, M. (1984). A régibb kőkor Magyarországon (The Palaeolithic in Hungary). In G. Székely (ed.), Magyarország története 1: elözmények és magyar történet 1242-ig. Volume 1 (pp. 69-116) Budapest: Akadémiai Kiadó.

Gutay, M. \& Kerékgyártó, Gy. (2019). Erk-1. - Mezolitikus lelőhely a Tarna völgyében (Erk 1 Mesolithic site in the Tarna Valley). Agria, Az egri Dobó István Vármúzeum Évkönyve 52 (2019), 35-55.

Horváth, T. \& Ilon, G. (2017). Mezőlak-Szélmező-Tőzegtelep: egy nem hétköznapi őskori lelőhely (Mezőlak-Szélmezö-Peatbog: an unusual prehistoric site). Archeometriai Mühely 14/3 (2017), 143-184.

Kaczanowska, M. \& Kozłowski, J. K. (2014). The origin and spread of the Western Linear Pottery Culture: between forager and the food producing lifeways in Central Europe. Archeologiai Értesitö 139 (2014), 293-318. http://dx.doi.org/10.1556/ArchErt.139.2014.12

Kertész, R. (1993). Data to the Mesolithic of the Great Hungarian Plain. Tisicum 8 (1993), 81-104.

Kertész, R. (1996). The Mesolithic in the Great Hungarian Plain: a survey of the evidence. In L. Tálas (ed.), At the Fringes of Three Worlds: Hunter-Gatherers and Farmers in the Middle Tisza Valley (pp. 5-34). Szolnok: Damjanich János Múzeum.

Kertész, R. (2002). Mesolithic hunter-gatherers in the northwestern part of the Great Hungarian Plain. Praehistoria: International Prehistory Journal of the University of Miskolc 3 (2002), 281-304.

Kertész, R. (2003). The Mesolithic: towards a production economy. InZs. Visy (ed.), Hungarian Archaeology at the Turn of the Millennium (pp. 91-95). Budapest: Ministry of National Cultural Heritage Teleki László Foundation.

Kertész, R. (2005). Tarnaörs-Fodor-tanya: egy új mezolit lelöhely az Észak-Alföldön [Tarnaörs-Fodortanya: A new Mesloithic site in the northern part of the Great Hungarian Plain]. Szolnoki Tudományos Közlemények 9 (2005), 1-53. 
Tibor Marton et al. $\bullet$ The Mesolithic Research of a Decade: Early Holocene Settlements in Transdanubia

Kertész, R. \& Demeter, O. (2020). Contributions to raw material studies of the Transdanubian early Mesolithic lithic industry: Szekszárd-Palánk. Praehistoria: International Prehistory Journal of theUniversity of Miskolc New Series 1-2 (11-12), 121-134.

Kozłowski, S. K. (2001). Eco-cultural/stylistic zonation of the Mesolithic/Epipalaeolithic in Central Europe. In R. Kertész \& J. Makkay (eds), From the Mesolithic to the Neolithic. Proceedings of the International Archaeological Conference held in the Damjanich Museum of Szolnok, September 22-27, 1996 (pp. 261282). Budapest: Archaeolingua.

Kozłowski, S. K. (2003). The Mesolithic: What do we know and what do we believe? In H. Kindgren, K. Knutsson, L. Larsson, D. Leoffler \& A. Åkerlund (eds), Mesolithic on the Move. Papers Presented at the Sixth International Conference on the Mesolithic in Europe, Stockholm 2000 (pp. xvii-xxvii). Oxford: Oxbow.

Kraus, D. (2011). Duna környéki epipaleolit és mezolit leletanyagok [Epipaleolithic and Mesolithic Finds in the Danube Region]. MA Thesis, Eötvös Loránd University, Budapest.

Krauss, R. (2016). The Mesolithic-Neolithic Transition in the Carpathian Basin. In R. Krauss \& H. Floss (eds), Southeast Europe before Neolithisation. Proceedings of the International Workshop within the Collaborative Research Centres sfb 1070 "RessourcenKulturen", Schloss Hohentübingen, 9th of May 2014, Vol. 1 (pp. 193-222). Tübingen: Universität Tübingen.

Makkay, J. (1970). A kökor és rézkor Fejér megyében. Fejér megye története az öskortól a honfoglalásig I/1 [The Stone Age and Copper Age in Fejér County. The History of Fejér County from the Stone Age to the Hungarian Conquest I/1]. Székesfehérvár: Fejér megyei Tanács.

Marosi, A. (1935). Öskőkori szigony Merítőpusztáról [Paleolithic bone harpoon from Csór-Merítőpuszta]. Székesfehérvári Szemle 5/3-4 (1935), 75-76.

Marosi, A. (1936a). A Székesfehérvári Múzeum őskori csontszigonya [The Stone Age bone harpoon from Csór-Merítőpuszta in the Museum of Székesfehérvár]. Archaeológiai Értesitő 54 (1936), 83-85.

Marosi, A. (1936b). Kormeghatározó adatok a csór-merítőpusztai őskori csontszigonyhoz [Data on the dating of the Stone Age bone harpoon from Csór-Merítőpuszta]. Székesfehérvári Szemle 6/1-2 (1936), 40-42.

Marton, T. (2002). Preliminary report on the stone tools recovered from the Early Copper Age site of Szombathely-Metro shopping centre. Antaeus 25 (2002), 325-336.

Marton, T. (2003). Mezolitikum a Dél-Dunántúlon - a somogyi leletek újraértékelése (Das Mesolithikum im südlichen Transdanubien - die Neubewertung der Funde aus dem Komitat Somogy). Móra Ferenc Múzeum Évkönyve - Studia Archaeologica 9 (2003), 39-48.

Mateiciucová, I. (2008). Talking Stones: The Chipped Stone Industry in lower Austria and Moravia and the Beginnings of the Neolithic in Central Europe (LBK), 5700-4900 BC. Dissertationes archaeologicae Brunenses/Pragensesque 4. Brno: Masarykova univerzita.

Mester, Zs., Faragó, N. \& Király, A. (2014).The first in situ Old Stone Age assemblage from the Rába Valley, Northwestern Hungary. Dissertationes Archaeologicae ex Instituto Archaeologico Universitatis de Rolando Eötvös nominatae 3/2 (2014), 351-362. https://doi.org/10.17204/dissarch.2014.351 
Tibor Marton et al. $\bullet$ The Mesolithic Research of a Decade: Early Holocene Settlements in Transdanubia

Nemeskéri, J. (1948). A mezolitikus kultúrának új nyoma Magyarországon [New evidence of Mesolithic culture in Hungary]. Természettudomány 3 (1948), 221-222.

Pusztai, R. (1957). Mezolitikus leletek Somogyból (Mesolithische Funde im Komitat Somogy). A Janus Pannonius Múzeum Évkönyve 1957, 96-105.

Tolnai-Dobosi, V. (1968): Kupferzeitliche Silexgeräte aus Ungarn. Acta Archaeologica Carpathica 10 (1968), 271-285.

Verhart, L. (2000). The function of Mesolithic bone and antler points. Anthropologie et Prèhistorie 111: La Chasse dans la Préhistoire. Hunting in Prehistory (2000), 114-123.

Vértes, L. (1965). Az öskökor és az átmeneti kökor emlékei Magyarországon [Finds from the Paleolithic and the Mesolithic in Hungary]. Budapest: Akadémiai Kiadó.

Vértes, L. (1962). Die Ausgrabungen in Szekszárd-Palánk und die archäologischen Funde. Swiatowit 24 (1962), 159-202. 